\title{
Remote Sensing Application for Exploring Land Use and Land Cover Dynamics in and Around Chatra Wetland, English Bazar, West Bengal
}

\author{
Saleha Jamal and Md Ashif Ali ${ }^{*}$ iD \\ Department of Geography, Aligarh Muslim University, Aligarh, Uttar Pradesh-202001, India \\ *asif4u.amu@gmail.com (Corresponding Author)
}

ARTICLE INFORMATION

Received: January 25, 2021

Revised: April 23, 2021

Accepted: May 28, 2021

Published Online: July 06, 2021

Keywords:

Land Transformation, Productive Ecosystem,

Urban Encroachment, Urban Expansion

\begin{abstract}
Wetlands are often called as biological "supermarket" and "kidneys of the landscape" due to their multiple functions, including water purification, water storage, processing of carbon and other nutrients, stabilization of shorelines and support of aquatic lives. Unfortunately, although being dynamic and productive ecosystem, these wetlands have been affected by human induced land use changes. India is losing wetlands at the rate of 2 to 3 per cent each year due to over-population, direct deforestation, urban encroachment, over fishing, irrigation and agriculture etc (Prasher, 2018). The present study tries to investigate the nature and degree of land use/land cover transformation, their causes and resultant effects on Chatra Wetland. To fulfil the purpose of the study, GIS and remote sensing techniques have been employed. Satellite imageries have been used from United States Geological Survey (USGS) Landsat 7 Enhanced Thematic Mapper plus and Landsat 8 Operational Land Imager for the year 2003 and 2018. Cloud free imageries of 2003 and 2018 have been downloaded from USGS (https://glovis. usgs.gov/) for the month of March and April respectively. Image processing, supervised classification has been done in ArcGis 10.5 and ERDAS IMAGINE 14. The study reveals that the settlement has increased by about 90.43 per cent in the last 15 years around the Chatra wetland within the buffer zone of $2 \mathrm{Sq} \mathrm{km}$. Similarly agriculture, vegetation, water body, swamp and wasteland witnessed a significant decrease by 5.94 per cent, 57.69 per cent, 26.64 per cent 4.52 per cent and 55.27 per cent respectively from 2003 to 2018 .
\end{abstract}

\section{Introduction}

Land use/land cover is an important phenomenon that reflects the intricate and multiplex interaction between the environmental factors and induced human activities, which brings land transformation. The impact of land transformation and land conversion degraded the quality of water and threatened wetland ecosystem (Fazal et al., 2011). The land transformations brought changes in morphometry, hydrology and biodiversity of a place besides validating a concurrent change in socioeconomic patterns of the local population (Jamal et al., 2019; Papa et al., 2011). Geospatial tools like ERDAS, Arc-GIS are employed for computing these changes in the geographical extent of vulnerable ecosystems (Jamal and Ajmal, 2020). Wetlands are biologically diverse and economically productive as well as an integral part of the ecosystem of the earth but are often undervalued and their conservation is neglected (Halls, 1997; Ganaie et al., 2020, Jamal \& Ahmad, 2020).
"Wetlands are the areas of marsh, fen, peat-lands or water, whether natural or artificial, permanent or temporary, with water that is static or flowing fresh or brackish or salt, including areas of marine water, the depth of which at low tide does not exceed meters" (Ramsar convention bureau, 2013). Wetlands are of immense value providing an innumerable supply of goods and services to humans, still they are threatened ecosystem in a region (Mitsch \& Gosselink, 2000). Wetlands perform multifarious ecological functions in water purification, flood protection, shoreline stabilization, groundwater recharge etc. and it also provides shelter and feeds thousands of different plants and animals (Boyer \& Polasky, 2004; Shafiq et al., 2019). Many of the functions and values often go unnoticed. Thus, being one of the valuable components of the ecosystem, providing diverse functions, wetlands are often narrated as "biological supermarket" and "kidneys of the landscape" (Mitsch \& Gosselink, 1993; Barbier et al., 1997). It also 
provides supporting services to the human society like ground-water recharging, flood control, water purification, water supply, soil protection but the agony is that these wetlands are also losing their overall qualities by the human interventions day by day (Wondefrash, 2003).

Unfortunately, being such dynamic and productive ecosystem, these wetlands have been affected by humaninduced land-use changes (Chen et al., 2018). The changes in land use not only change the morphology of the area but also bring changes in average temperature and humidity regimes, thereby endorsing a concurrent change in socio-economic patterns of the inhabiting local community. The disintegration and degradation of wetlands are greatly attributed to agricultural and settlement reclamations, resulting in negative ecological consequences like flooding, declining of biodiversity and extinction of several endemic species. Consequently, qualities of water in most wetlands have also been heavily deteriorated, due to waste water and effluent discharges, causing widespread eutrophication (Zhao et al., 2005).

Malda district is gifted with magnificent wetlands and water bodies. These wetlands in the district are both perennial and seasonal in nature; most of them are connected with the major rivers like Ganga, Mahananda, Kalindri, Tangon, Pagla, Punarbhaba and other small streams that flow through the district. Among these wetlands some are very old and originated naturally and some are artificial in nature (Chowdhury, 2009). According to National Wetland Atlas 2010, the district has 4939 wetlands out of which 502 wetlands are more than 2.25 hectare while 4437 are less than 2.25 hectare. Out of 502 wetlands, 382 are natural and the remaining 120 are artificial in nature. The district records the maximum number of wetlands because of its low lying surface in the state. This low-lying topography favours the formation of numerous ox bow lakes by the Kalindri River (Das, 2016). Seasonal variation of water spreading is the normal phenomenon in the district. In post-monsoon the area covered by the wetlands is 19384 hectares which decrease up to 15295 hectares in pre monsoon (NWIA, 2010). Owing to the location and significance, Chatra wetland has been chosen to conduct the present study. This wetland also experiences seasonal variation such as approx 142-hectare area is occupied by the water in post-monsoon and only 65 hectares in pre-monsoon (Kar, 2014). The Chatra wetland is an artificial wetland formed due to the construction of NH34, embankment of railways, afflux embankment (after Farakka barrage 1974). These embankments have shut off the natural drainage line and thus stagnant water started accumulating in the low land. The wetland also considered as the lung of the town (Kar, 2018). It provides numerous services to the local people living around it, including fishing, gorgon cultivation, agriculture, irrigation, medicinal plants, fodder, recreation and aesthetic values. The present research work inquires the general pattern of urban expansion and land transformation in and around Chatra wetland. The study aims to focus on the impact of these land transformations on Chatra wetland.

\section{Study Area}

The study has been conducted on Chatra wetland located in the Malda district of West Bengal. This is one of the largest artificial wetlands in the district (Kar, 2018). The latitudinal and longitudinal extent of the wetland lies between $24^{\circ} 58^{\prime} 56^{\prime \prime} \mathrm{N}$ to $25^{\circ} 00^{\prime} 09^{\prime \prime} \mathrm{N}$ and $88^{\circ} 06^{\prime} 38^{\prime \prime} \mathrm{E}$ to $88^{\circ} 08^{\prime} 10^{\prime \prime} \mathrm{E}$. The wetland is located at the elevation of 29 metres above mean sea level in the south-west part of the district. The Chatra wetland has an area of about 142 hectares (Director of Fisheries, Malda District, 2009). The entire district constitutes of three physiographic divisions i.e. Tal, Diara and Barind region. The particular wetland lies in the Diara region and stretching from the north-west to the south-east direction in the English Bazar block. It has been found that the surrounding area of the wetland has a significant LULC change by different categories. Being the only functional town, people are attracted to settle here. The settlement is only increasing in the north-eastern side of the wetland due to its suitable location. The other side of the municipality has low built-up due to the presence of the river Mahananda. The municipality population has increased from 161,456 (census 2001) to 205,521 (Census 2011) and this expansion of population requires more land to settlement and agriculture. To fulfil their requirement they started land reclamation along the wetland. Remarkable LULC change has been seen along the wetland. For indepth analysis, the study area was demarcated by 2 Sq. km buffer around the Chatra wetland. 


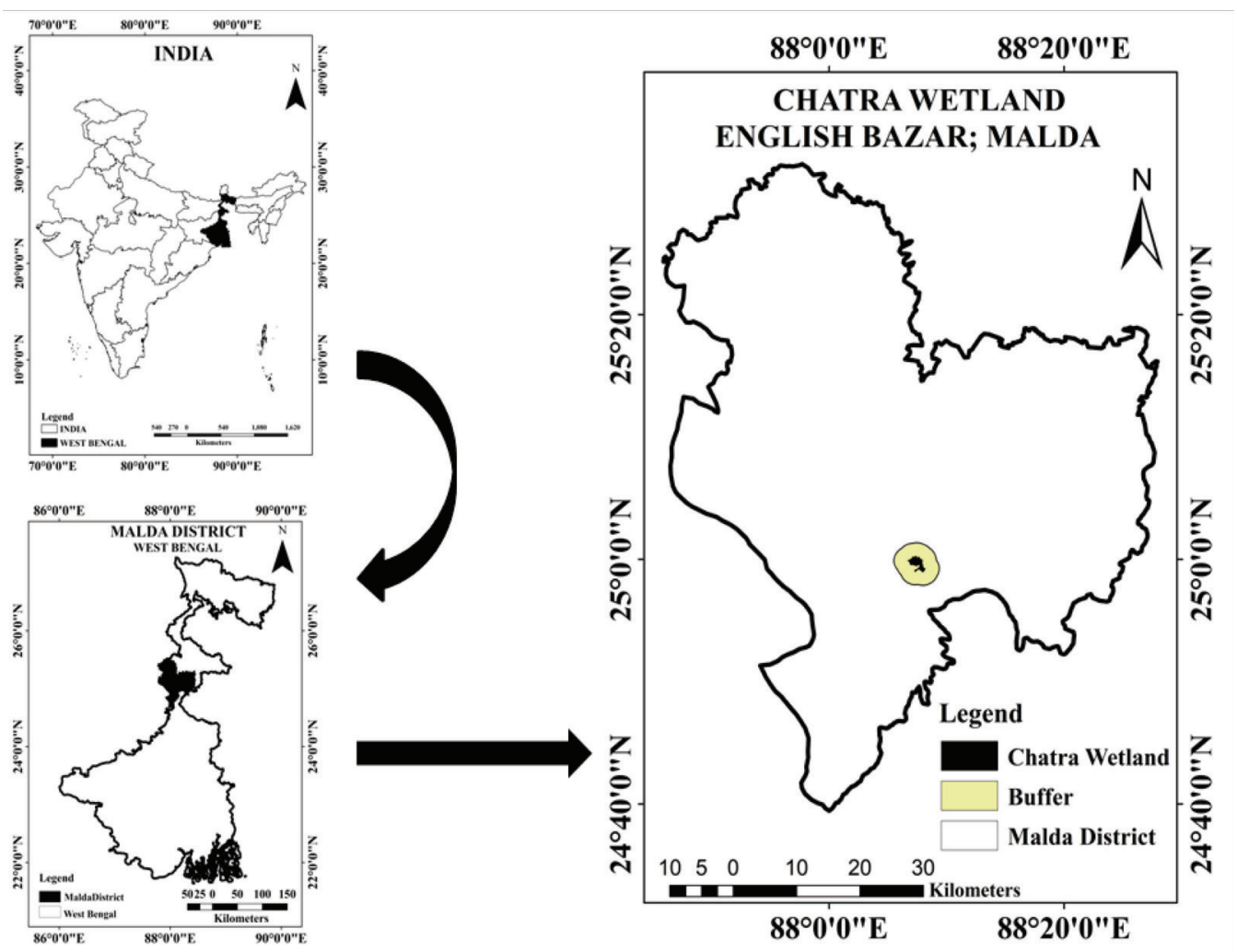

Figure 1: Locational Map of Chatra Wetland, English Bazar, Malda.

\section{Contribution of Chatra Wetland Resources to the Household Economy}

Throughout the globe, all the people living in and around wetlands are getting benefited by the wetland resources directly or indirectly (Das et al., 2015). Similarly, a field survey reveals that the community living around the Chatra wetland are blessed by many natural resources available in the wetland, which contributed significantly to the household economy. Products from the wetland kalmi (water spinach), sushni (dwarf water clove), hingcha (water cress), kulkhera (swampweeds), thankuni (Indian pennywort) etc, are used for medicinal purposes by the locals (Kar, 2014). People collect many items from the wetland like food, fodder, fuel, building material and plants. Some wetland dependent communities sell these products in local market and earn up to 55.02 USD per month individually (field survey, 2018). Fishing has been reported as the main occupation for some people to sustain their lives. Another important aspect is the cultivation of gorgon nut, which has a significant demand in the international market throughout the world. Now, this crop has been accepted for "International commercial crop" (Kar, 2018). The people, who are living around the wetland, get a high amount of economic support from gorgon cultivation, chest-nut and lotus for their market demand (Dutta et al., 2015). It is also observed that another commercial crop jute has a significant demand in the region. Cultivation and production of jute in the area has an important role in the household's economy. The farmers use the wetland water for jute retting (the process of extracting fibres from the long-lasting life stem or bast fibre plants) because of slow water motion which is favourable for jute retting.

\section{Wetland Degradation}

Wetlands are being destroyed and degraded; we have lost more than 50 per cent of the total wetland since 1900AD (Davidson, 2014). India is losing wetlands at the rate of 2 to 3 per cent each year due to overpopulation, direct deforestation, urban encroachment, over fishing, irrigation (Prasher, 2018). Migration also plays a vital role in decreasing the wetland area; people choose the wetland area to practice land reclamation 
for making their residential zone and economic land (Demnati et al., 2012). Wetlands are used as a dumping site by filling domestic materials and other garbage (Jamal et al., 2020; Islam et al., 2010). Apart from these, rapid construction of residential buildings and filling up the wetland played a vital role in reduction of the wetland area (Leisangthem et al., 2012). Unscientific application of toxic materials like fertilizer, pesticides and insecticides in the agricultural fields located around the wetland area is constantly polluting the wetland ecosystem (Byomkesh et al., 2009). The Chatra wetland became a dumping site for the occupants and as well as for the residents of the town. The sewerage system of the whole town connected with the wetland. Both solid and liquid wastes dumped from the households in the wetland resulted in surface water exploitation (Kar, 2018). The increasing human population in wetland area is threatening the wetland species and migratory birds (Turner et al., 2000). Another threatening aspect for the wetland species and migratory bird is human intervention in the wetland. Locals are trapping and hunting birds for food, resulting into serious decline of bird population in the wetland, which is the major loss for the wetland habitat.

It has been noticed that, gorgon (fox nut) cultivation is a dominant tradition in the wetland as well as in the district. The cultivation of gorgon nut in the wetland needs removal of many aquatic plants, weeds, herbs, shrubs, fishes, crabs, earthworms and snakes etc (Khatun et al., 2012), which directly disturbs the wetland ecosystem. The wetland is suitable for gorgon cultivation. Gorgon nut (Euryale Ferox Salisb) has less economic input and high return output. Along with this the gorgon nut supports local population in their household economy but on the other hand threatens the aquatic plants and diversity. The cultivation needs the elimination of plants and species from the water which directly damage the wetland habitats.

The field survey of the study area reveals that the Chatra wetland of Malda district is also declining at a faster rate, due to urban encroachment and different types of land uses.

\section{Material and Methods}

To fulfil the objectives of the study, Remote Sensing and Geographical Information System (GIS) techniques have been used. Satellite imageries Landsat-7 Enhanced
Thematic Mapper plus and Landsat-8 Operational Land Imager have been downloaded from USGS for the year 2003 and 2018. Satellite imageries of 2003 and 2018 were downloaded for the month of March and April respectively. The months were chosen for the clear atmosphere and cloud free sky. Spatial resolutions of both the images were $30 \mathrm{~m}$. For image classification band 2, 3, 4, 5, 7 and panchromatic bands were used. Image processing followed by supervised classification (with maximum likelihood classifier) was done in ArcGis 10.5 and ERDAS IMAGINE 14., to get the desired output and to calculate the area of the water body, settlement, swamp, wasteland, agriculture and vegetation. The change detection of LULC has been calculated for the time period 2003 and 2018 . Moreover, for gaining an intuitive knowledge of the study area, field visit has been done.

\section{Result \& Discussion}

The study involved mapping of about $31.58 \mathrm{Sq}$. Km in and around the Chatra wetland of English Bazar to detect the change in different classes from 2003 to 2018. A total of six classes has been identified in the study area i.e. settlement, agriculture, vegetation, water body, swamp and wasteland. The analysis of the LULC dataset of 2003 reveals that about 7.63 Sq. Km area have been lying under the settlement. The settlement increased along the south-western boundary as compared to the north-eastern boundary of the municipality due to the presence of the Mahananda River. It has been found that the area under agriculture is one of the main activities, about $9.43 \mathrm{Sq}$. Km. Water bodies act as the life-line to the surrounding area, which constitutes an area of about $2.89 \mathrm{Sq}$. Km i.e. 9.15 per cent of the study area, swamps cover about $1.99 \mathrm{Sq}$. Km. As per the dataset, wasteland (which includes fallow lands, barren lands, open spaces, land under airport authority) class is considered, which occupies the area of $2.37 \mathrm{Sq}$. Km while the vegetation (including orchards and mango trees) covers an area of $9.43 \mathrm{Sq}$. Km of the study area (Table 1 and Figure 2). Dataset of 2003 reveals that the study area was having ample distribution of water bodies. But the area under water bodies significantly decreased in 2018 which affects the household's economy of the community living around the wetland. 
Table 1: Area under different LULC categories of Chatra Wetland (2003).

\begin{tabular}{|l|l|l|}
\hline Classes & $\begin{array}{l}\text { March } \\
\mathbf{2 0 0 3} \\
\text { Area in Sq. Km }\end{array}$ & Percentage \\
\hline Settlement & 7.63 & $24.16 \%$ \\
\hline Agriculture & 9.43 & $29.86 \%$ \\
\hline Vegetation & 7.28 & $23.05 \%$ \\
\hline Water body & 2.89 & $9.15 \%$ \\
\hline Swamp & 1.99 & $6.30 \%$ \\
\hline Wasteland & 2.37 & $7.50 \%$ \\
\hline Total & $\mathbf{3 1 . 5 8}$ & $\mathbf{1 0 0} \%$ \\
\hline
\end{tabular}

Source: Calculated from the supervised classification of Landsat 7 ETM+ (2003)

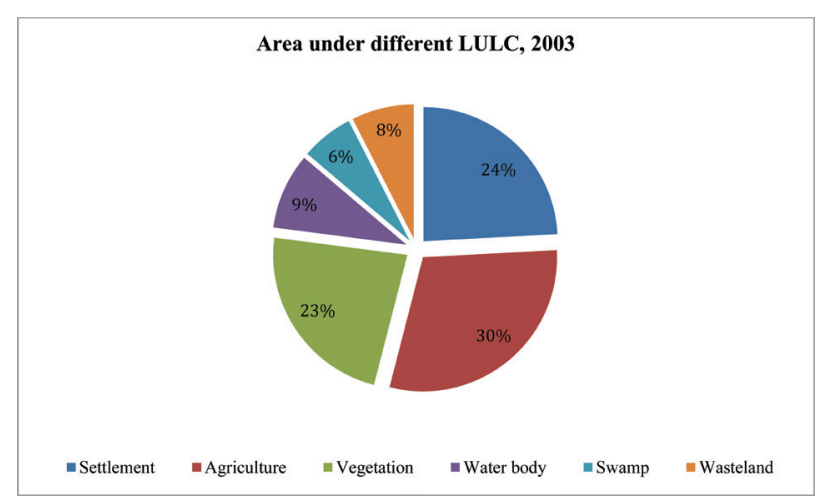

Figure 2: Area under different LULC categories of Chatra Wetland (2003).

Similarly, analysis of computed satellite data for the year 2018 revealed noticeable change from 2003 to 2018. A perusal of Table 2 and Figure 3 shows that nearly $14.53 \mathrm{Sq}$. Km (46.01 per cent) has been found lying under settlement area mostly on north, north-eastern and southern side of the Chatra wetland. Considering the agriculture class, it covers second largest area of about $8.87 \mathrm{Sq}$. Km (28.09 per cent) of the total study area. However, mapping of waterbodies shows that in 2018 it occupies only $2.12 \mathrm{Sq} . \mathrm{Km}$ (6.71 per cent) which clearly reveals that several water bodies have been encroached. The remaining categories such as vegetation, swamp and wasteland occupies an area of $3.08 \mathrm{Sq}$. Km $(9.75$ per cent), 1.90 Sq. Km (6.02 per cent) and 1.08 Sq. Km (3.42 per cent) respectively.
Table 2: Area under different LULC categories of Chatra Wetland (2018).

\begin{tabular}{|l|l|l|}
\hline Classes & $\begin{array}{l}\text { April 2018 } \\
\text { area in Sq. Km }\end{array}$ & Percentage \\
\hline Settlement & 14.53 & $46.01 \%$ \\
\hline Agriculture & 8.87 & $28.09 \%$ \\
\hline Vegetation & 3.08 & $9.75 \%$ \\
\hline Water body & 2.12 & $6.71 \%$ \\
\hline Swamp & 1.90 & $6.02 \%$ \\
\hline Wasteland & 1.08 & $3.42 \%$ \\
\hline Total & $\mathbf{3 1 . 5 8}$ & $\mathbf{1 0 0} \%$ \\
\hline
\end{tabular}

Source: Calculated from the supervised classification of Landsat 8 OLI (2018)

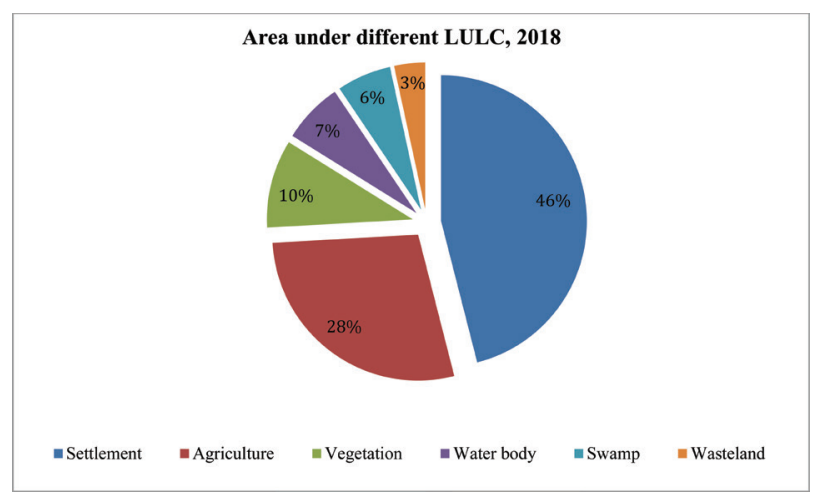

Figure 3: Area under different LULC categories of Chatra Wetland (2018).

A perusal of Table 3 reveals that the changes of LULC classes in the study area during the study period. However, in 2018 the area under settlement has increased and covered an area of $14.53 \mathrm{Sq}$. Km. The rate of growth is about +90.43 per cent in one and half decade. The tremendous rise of settlement in the study area is due to increasing population, as more population required more infrastructure, houses and facilities. Agricultural land has also decreased in 2018 with negative growth of -5.94 per cent and occupied an area of $8.87 \mathrm{Sq}$. Km. as compared with $9.43 \mathrm{Sq}$. $\mathrm{Km}$ in 2003. A remarkable change (-57.69 per cent) in vegetation category has been found as the area under vegetation was $7.28 \mathrm{Sq}$. Km in 2003 which decreased significantly to $3.08 \mathrm{Sq}$. Km in 2018. Similarly, the water body lost its area of $2.89 \mathrm{Sq}$. Km in 2003 to 
2.12 Sq. Km in 2018 with negative change of -26.64 per cent. The least change found in the area of the swamp category with negative change $(-4.52$ per cent) from 2003 to 2018. In the study site, the area under wasteland was 2.37 per cent in 2003 and decreased to 1.08 per cent in 2018 . The total area has found negative change of -55.27 per cent during the study period.

Table 3: Area under different classes in 2003 and 2018.

\begin{tabular}{|l|l|l|l|l|l|}
\hline Classes & $\begin{array}{l}\text { March 2003 area } \\
\text { in Sq. Km }\end{array}$ & $\begin{array}{l}\text { Percentage to } \\
\text { total area }\end{array}$ & $\begin{array}{l}\text { April 2018 } \\
\text { area in Sq. Km }\end{array}$ & $\begin{array}{l}\text { Percentage to } \\
\text { total area }\end{array}$ & $\begin{array}{l}\text { Percentage } \\
\text { growth }\end{array}$ \\
\hline Settlement & 7.63 & $24.16 \%$ & 14.53 & $46.01 \%$ & $90.43 \%$ \\
\hline Agriculture & 9.43 & $29.86 \%$ & 8.87 & $28.09 \%$ & $-5.94 \%$ \\
\hline Vegetation & 7.28 & $23.05 \%$ & 3.08 & $9.75 \%$ & $-57.69 \%$ \\
\hline Water body & 2.89 & $9.15 \%$ & 2.12 & $6.71 \%$ & $-26.64 \%$ \\
\hline Swamp & 1.99 & $6.30 \%$ & 1.90 & $6.02 \%$ & $-4.52 \%$ \\
\hline Wasteland & 2.37 & $7.50 \%$ & 1.08 & $3.42 \%$ & $-55.27 \%$ \\
\hline Total & $\mathbf{3 1 . 5 8}$ & $\mathbf{1 0 0 \%}$ & $\mathbf{3 1 . 5 8}$ & $\mathbf{1 0 0 \%}$ & \\
\hline
\end{tabular}

Source: Compiled by the authors on the basis of supervised classification of raster datasets

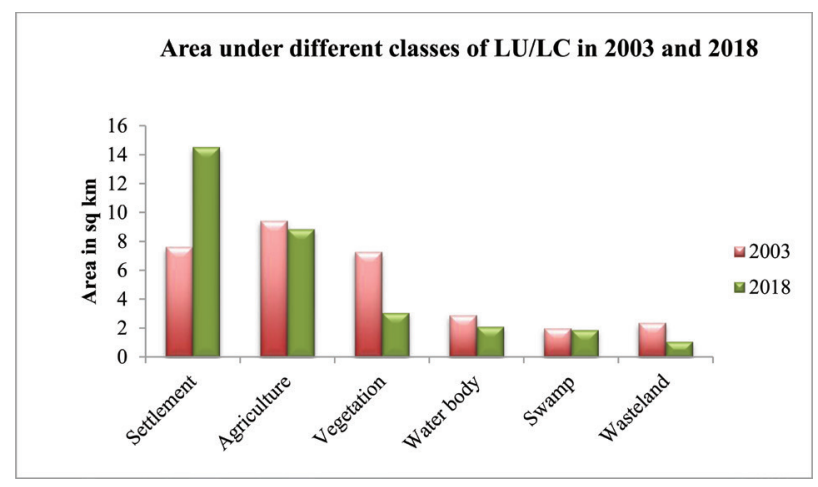

Figure 4: Area under different classes of LULC in 2003 and 2018.

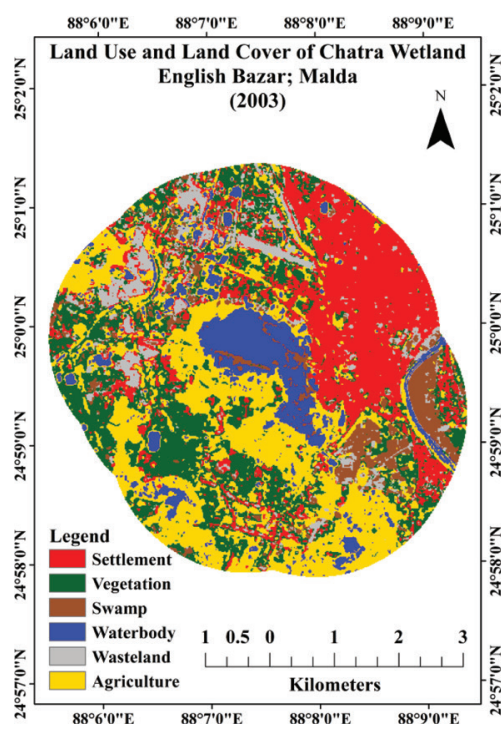

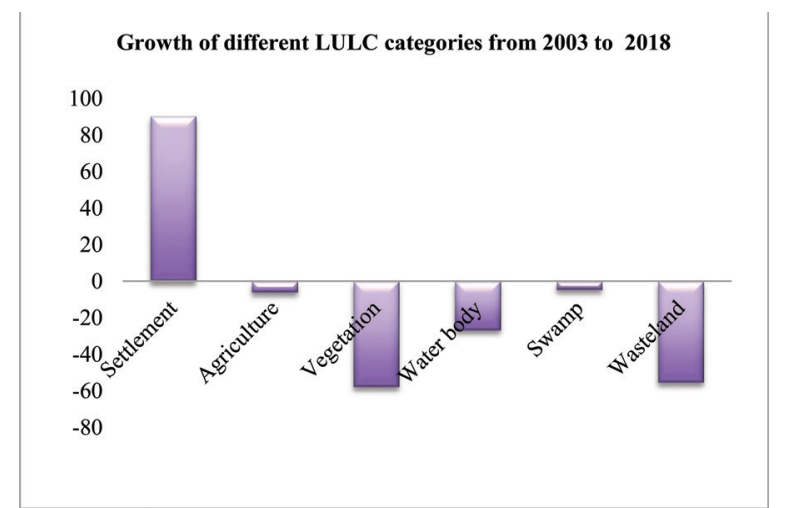

Figure 5: Growth of different LULC categories from 2003 to 2018.

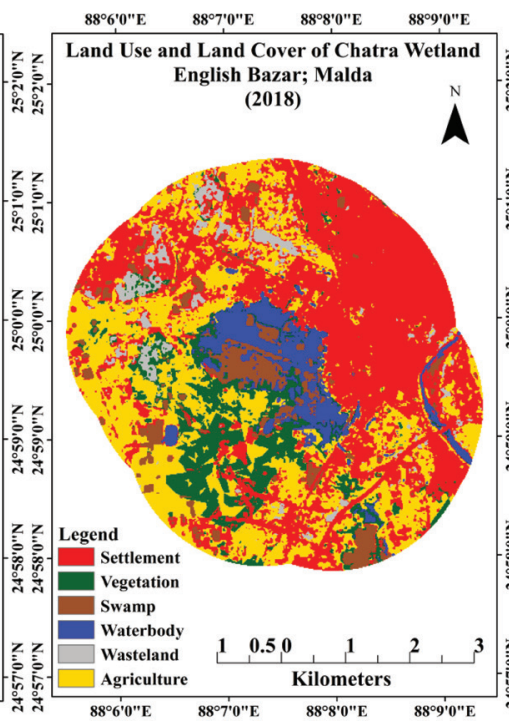

Figure 6: LULC map of different classes for Chatra wetland in 2003 and 2018. 
For better understanding, each class has been extracted from the classified imageries of 2003 and 2018. It is clear that the images depict a significant change in terms of area coverage from 2003 to 2018 (Figure 7). The area under settlement shows a massive change of land use in the north-eastern part from 2003 to 2018. On the other side the area under agriculture got decreased in the year 2018 as compared to 2003. The map of vegetation cover depicts a notable change from 2003 to 2018 i.e. it occupied more area in the year 2003 but revealed a significant loss in the year 2018. Similarly, the area under water body and swamp also decreased during the assessment period. A remarkable change of the wasteland category has been found which lost more than 50 per cent of its total area in 2018 (Figure 7).
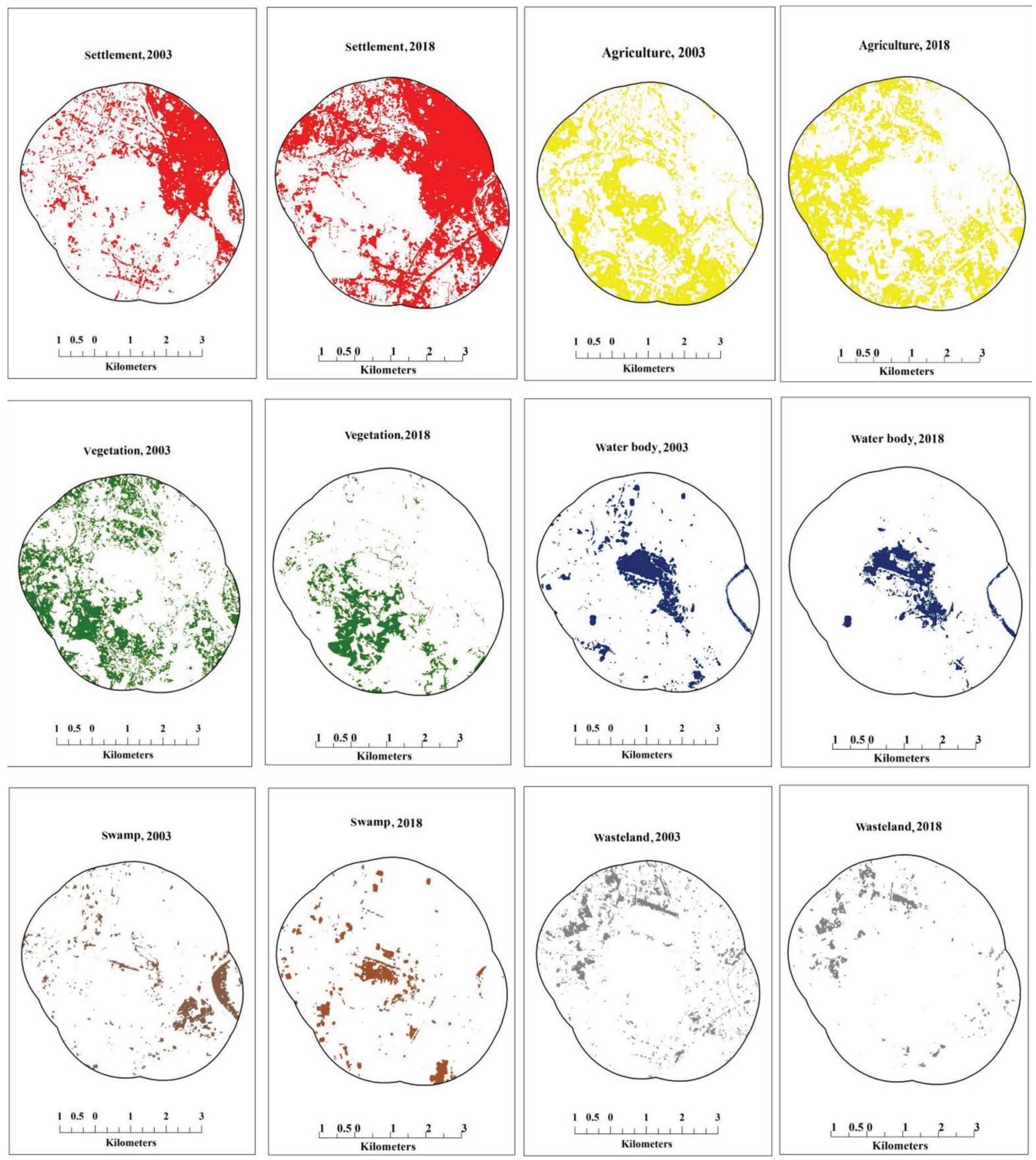

Figure 7: Area under different LULC classes in 2003 and 2018. 


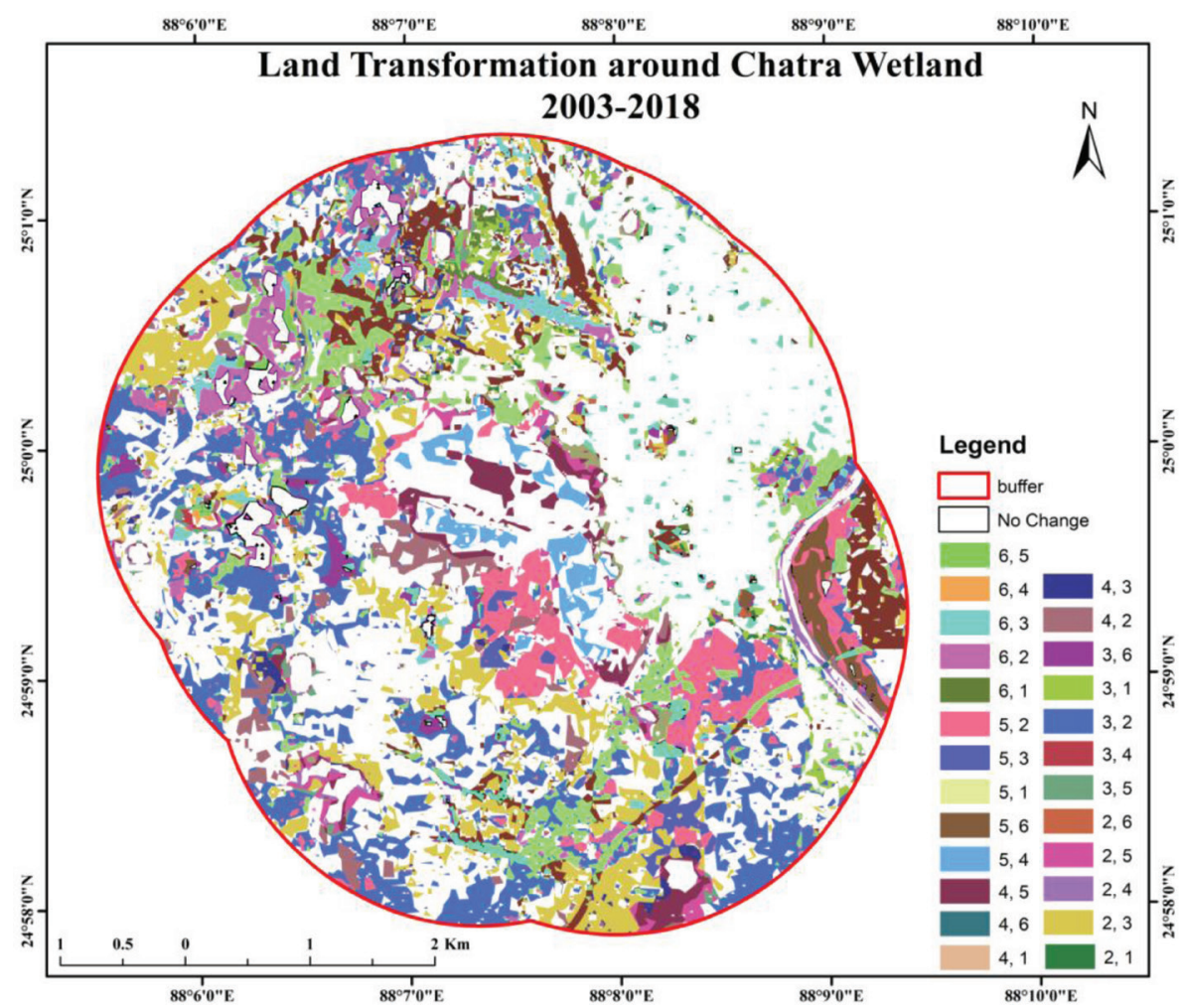

Index: $6=$ Agriculture, $5=$ Wasteland, $4=$ Water body, $3=$ Swamp, $2=$ Vegetation, $1=$ Settlement

Figure 8: Land transformation around Chatra Wetland (2003-2018).

Table 4: Land use/land cover transformation matrix (area in Sq. Km).

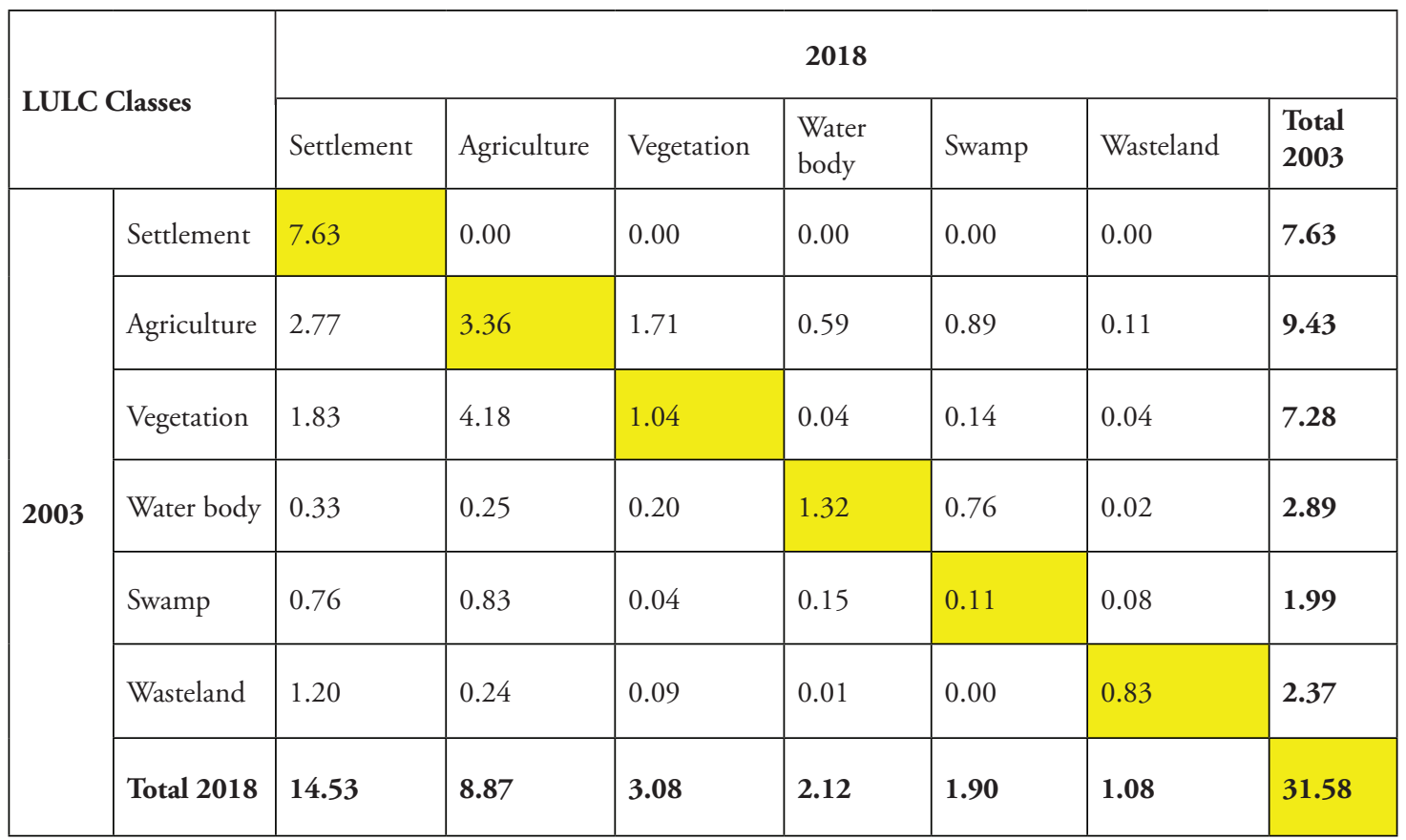

Source: Image statistical results retrieved from error Matrix. 


\section{Land use dynamics in the study area}

The analysis of table 4 and figure 8 shows a significant land use land cover change during the study period (2003-2018). To know the type and level of land encroachment in the last one and half decade (20032018), it was essential to evaluate a change detection matrix (table 4). The analysis of the error matrix (Table 4) reveals about the loss and gain of land use categories and unchanged area under different LULC classes. The total area under six classes occupied 31.58 Sq. Km.

\section{LULC in 2003}

A total of six LULC categories were classified to assess the land-use dynamics in the study area viz., Settlement, agriculture, vegetation, water body, swamp and wasteland from 2003 to 2018. From statistics of LULC the total area under investigation was 31.58 Sq. Km (Table 4, Figure 8). The area under settlement class was found to be $7.63 \mathrm{Sq}$. Km in the year 2003 . Agriculture occupied an area of about $9.43 \mathrm{Sq}$. Km, which was the most prominent category of LULC in the study area in 2003. Vegetation cover occupied an area of 7.28 Sq. Km followed by $2.89 \mathrm{Sq}$. Km, 2.37 Sq. $\mathrm{Km}$ and $1.99 \mathrm{Sq}$. Km for waterbody, wasteland and swamp.

\section{LULC in 2018}

The statistics of raster classified maps of the study area revealed that area under settlement, agriculture, vegetation, water body, swamp and the wasteland was 14.53 Sq. Km, 8.87 Sq. Km, 3.08 Sq. Km, 2.12 Sq. $\mathrm{Km}, 1.90 \mathrm{Sq} . \mathrm{Km}$ and $1.08 \mathrm{Sq} . \mathrm{Km}$ respectively in the study period 2018. Thus, it is clear that settlement occupies the maximum share in the study area, and wasteland with the least area. The probable cause for the maximum area under settlement in the study area can be associated to increase in growth rate of the population which in turn requires the increase in demand for infrastructural facilities like housing. The water body which is the basis for sustenance of life, has lost its area hence, depicts that this natural resource is under anthropogenic stress.

\section{LULC Transformation in the Study Area}

In the present study a notable change of LULC has been found in the study area. Table 4, shows LULC transformation matrix, which revealed that both the positive and the negative growth rate of different classes of land use in the study area, has taken place from 2003 to 2018. Figure 8, shows LULC change from 2003 to 2018 in the study area. In one and half decade, built-up has increased around the wetland in a significant manner; negative growth has been seen in the five classes out of six. Out of the six classes, settlement revealed a positive growth rate and the remaining five classes, agriculture, vegetation, water body swamp and wasteland depicted negative growth rate.

\section{Settlement}

The analysis of our study reveals that a remarkable change in built-up category has been seen in the poststudy. In 2003 the share of built-up was 24.16 per cent which increased up-to 46.01 per cent in 2018 (Table 3). Thus, registering an increasing rate of change in the settlement category is +90.43 per cent from 2003 to 2018. Escalating population pressure in the study area is considered as the major reason for a notable change in built-up category. The remarkable increase in rate of settlement class was significant around the wetland on its North-Eastern part.

\section{Agriculture}

Agriculture is the main activity in the district where most of the population is depending on agricultural activities to feed their dependent ones. Agriculture occupies 29.86 per cent of the total area in 2003. However, it declined to 28.09 per cent in 2018 and lost an area of $1.77 \mathrm{Sq}$. Km from 2003 to 2018. From error matrix, it is clear that it lost an area of $2.77 \mathrm{Sq}$. $\mathrm{Km}, 1.71$ Sq. Km, 0.59 Sq. Km, 0.89 Sq. Km and $0.11 \mathrm{Sq}$. Km to settlement, vegetation, water body, swamp and wasteland from 2003 to 2018 . However, at the same time it also encroached on other classified categories and gained an area of $4.18 \mathrm{Sq}$. Km, 0.25 Sq. $\mathrm{Km}, 0.83 \mathrm{Sq} . \mathrm{Km}$, and $0.24 \mathrm{Sq}$. Km from vegetation, water body, swamp and wasteland respectively. Thus, we can say that this category lost as well as gained area from 2003 to 2018, but the area lost was more than the area gained. However, an area of about 3.36 Sq. $\mathrm{Km}$ remained unchanged from 2003- 2018 in this category of land use (Table 4, Figure 8).

\section{Vegetation}

Vegetation is an important natural phenomenon on the earth surface which plays an important role to maintain 
the balance of the environment. Vegetation occupies 23.05 per cent of the total area in the year 2003. It lost an area of $4.20 \mathrm{Sq} . \mathrm{Km}$ in the studied time period. In terms of percentage it declined to 13.30 per cent in the year 2018. From 2003 to 2018 the vegetation-covered area transformed into settlement $(1.83 \mathrm{Sq} . \mathrm{Km})$, agriculture (4.18 Sq. Km), water body (0.04 Sq. Km), swamp (0.14 Sq. Km) and wasteland (0.04 Sq. Km). At the same time it also gained the area from other classified categories viz., agriculture (3.36 Sq. Km), water body $(0.20 \mathrm{Sq} . \mathrm{Km})$, swamp $(0.04 \mathrm{Sq} . \mathrm{Km})$ and wasteland $(0.09 \mathrm{Sq} . \mathrm{Km})$. Thus, it is clear from the error matrix that the vegetation class experienced both lost and gained area from 2003 to 2018. The matrix also clarified that the area under vegetation was more in 2003 and less in 2018; however, 1.04 Sq. Km area remains unchanged in the study period (Table 4, Figure 8).

\section{Water Body}

Water bodies are the prominent characteristic of nature and play a vital role in maintaining the ecological balance. However, a remarkable change has occurred in the water body of the study area during the assessment period from 2003 to 2018. A negative change ( -26.64 per cent) of the water body has been found in the study area from 2003 to 2018 . The area under water body was $2.89 \mathrm{Sq}$. Km in 2003 and it decreased to 2.12 Sq. Km in 2018. The transformation matrix shows that it is the least occupied area among all classes. Table 8 reveals that, $0.77 \mathrm{Sq}$. Km area of water body lost in the study period. It has been found that the water body has lost an area of $0.33 \mathrm{Sq} . \mathrm{Km}$, 0.25 Sq. Km, 0.20 Sq. Km, 0.76 Sq. Km, 0.02 Sq. $\mathrm{Km}$ to settlement, agriculture, vegetation, swamp and wasteland respectively from 2003 to 2018 . On the other hand, it also gained area from different classes viz., 0.59 Sq. Km, 0.04 Sq. Km, 0.15 Sq. Km and $0.01 \mathrm{Sq} . \mathrm{Km}$, from agriculture, vegetation, swamp and wasteland respectively in the assessment period. From 2003 to 2018, area under water body (1.32 Sq. Km) remains the same in the study area (Table 4, Figure 8). The loss of the water body in the study area is directly related to human intervention and encroachment. Construction of residential buildings, roads, farms and disposing sites in and around the water body are the main causes for declining its area.

\section{Swamp}

During 2003 to 2018 a negative change (-4.52 per cent) of swamp area has been found. The total area under swamp was $1.99 \mathrm{Sq}$. Km in 2003 and it decreased to $1.90 \mathrm{Sq}$. Km in 2018, which lost an area of $0.09 \mathrm{Sq}$. Km. From the error matrix it is clear that the area of swamp transformed into other classified classes, i.e. area occupied by settlement $(0.76 \mathrm{Sq}$. Km), agriculture $(0.83 \mathrm{Sq} . \mathrm{Km})$, vegetation $(0.04 \mathrm{Sq} . \mathrm{Km})$ and water body (0.15 Sq. Km) from 2003 to 2018. As well as the swamp category gained area from different classified categories such as agriculture (0.89 Sq. Km), vegetation $(0.14 \mathrm{Sq} . \mathrm{Km})$, water body $(0.76 \mathrm{Sq} . \mathrm{Km})$ in the study period. However, $0.11 \mathrm{Sq}$. Km area under swamp remains unchanged from 2003 to 2018 (Table 4, Figure 8).

\section{Wasteland}

A moderate change of land use has been found in the wasteland category from 2003 to 2018. A negative growth rate $(-55.27$ per cent) occurred in this category in one and half decade. In terms of the total area occupied by wasteland was $2.37 \mathrm{Sq}$. Km in 2003 and 1.08 Sq. Km in 2018 (Table 3). From the 2003 to 2018 the wasteland category has lost an area of $1.29 \mathrm{Sq}$. Km. the transformation matrix shows that the wasteland has lost an area of $1.20 \mathrm{Sq}$. Km, 0.24 Sq. Km, 0.09 Sq. Km, 0.01 Sq. Km to settlement, agriculture, vegetation, water body and swamp from 2003 to 2018. Similarly, the area gained from different classified categories of agriculture, vegetation, water body and swamp at the amount of $0.11 \mathrm{Sq}$. Km,0.04 Sq. $\mathrm{Km}$ and $0.02 \mathrm{Sq} . \mathrm{Km}$ and 0.08 respectively in the study period (Table 4, Figure 8). The wasteland category lost and gained its area from 2003 to 2018 but it has lost more area in 2018 than 2003. The area of $0.83 \mathrm{Sq}$. Km under wasteland was remained the same during the study period.

\section{Conclusion}

The change analysis between 2003 and 2018 has clearly pointed out towards the fact that the development in the study area has swallowed a significant proportion of vegetation and water bodies of Chatra wetland. The landuse change with the loss of vegetation and waterbodies can be attributed to heavy population pressure. As a 
result, the increasing population has encroached the wetland area rigorously, for instance, Krishna pally, Malancha pally, Aurobindo park and Netaji park areas are constantly encroaching the Chatra wetland and filling it for built-up. The present study finds out that in 2003 the built-up area was only 7.63 Sq. Km and which has increased to $14.53 \mathrm{Sq}$. Km in 2018. The growth rate of settlement in 15 years is +90.43 per cent which significantly denote, the population pressure in the study area which plays an important role to change the land use and land cover pattern. Another class like wasteland (which includes fallow lands, barren lands, open spaces, land under airport authority), has been found with negative growth, i.e. in 2003 the area under wasteland was $2.37 \mathrm{Sq}$. Km which has decreased to $1.08 \mathrm{Sq}$. Km in the year 2018. Area under vegetation (including orchards and mango gardens) was 7.28 Sq. Km in 2003 and decreased to $3.08 \mathrm{Sq}$. $\mathrm{Km}$ in 2018. More than 50 per cent area of vegetation has been lost during the studied period. Similarly, other classes of land use/land cover depicts a noteworthy change in their respective areas like agriculture (-5.94 per cent), waterbodies (-26.94 per cent), swamp areas ( -4.52 per cent). The heavy population pressures, haphazard encroachment, loss of vegetation, horticulture and gorgon nut cultivation have emerged as important factors that enhance the LULC change of the study area. The intrusion of municipal waste-water through drains into the wetland ecosystem has reinforced its degradation. This pathetic situation of the wetland under investigation demand immediate planning measures and attention of governmental and NGO'S for its sustainability before it is too late. Further it also requires operational sewage treatment plants so that no untreated sewage is disposed off to the wetland as it acts as a life-line for the town and also provides livelihood to a large number of local population. To control the built-up encroachment and human intervention in and around the wetland, there is an urgent need to pay attention to these unplanned concrete jungles for the maintained and ecological balance of these fragile ecosystems of nature. To bring these steps in action in reality, strong will and mass awareness regarding the benefits of such ecosystem among the local people is prerequisite.

\section{Acknowledgement}

The authors are highly thankful to anonymous reviewers for their valuable suggestions for improving the overall quality of the research work. Authors are also indebted to the Aligarh Muslim University for providing necessary equipment to conduct the research. The corresponding author is also highly grateful to UGC for providing fellowship throughout the research.

\section{References}

Barbier, E.B., Acreman, M., \& Knowler, D. (1997). Economic valuation of wetlands: a guide for policy makers and planners. Gland, Switzerland: Ramsar Convention Bureau.

Boyer, T., \& Polasky, S. (2004). Valuing urban wetlands: A review of non-market valuation studies. Wetlands, 24(4), 744-755. https://doi. org/10.1672/0277-5212(2004)024[0744:VUWARO ]2.0.CO;2

Byomkesh, T., Nakagoshi, N., \& Shahedur, R.M. (2009). State and management of wetlands in Bangladesh. Landscape and Ecological Engineering, 5(1), 81-90. https://doi.org/10.1007/s11355-008-0052-5

Chen, H., Zhang, W., Gao, H., \& Nie, N. (2018). Climate change and anthropogenic impacts on wetland and agriculture in the Songnen and Sanjiang Plain, Northeast China. Remote Sensing, 10(3), 356. https://doi.org/10.3390/rs10030356

Chowdhury, M. (2009). Plant diversity and vegetation structure in the wetlands of Malda district of West Bengal India. Department of Botany, University of North Bengal.

Das, S., Behera, B., \& Mishra, A. (2015). Determinants of household use of wetland resources in West Bengal, India. Wetlands Ecology and Management, 23(5), 803816. https://doi.org/10.1007/s11273-015-9420-8

Das, S. (2016). Fluvio-Ecological Modifications and Livelihood options of an Oxbow lake of Kalindri River, Malda District, West Bengal, India. International Research Journal of Earth Sciences, 4(7), 1-14.

Davidson, N.C. (2014). How much wetland has the world lost? Long-term and recent trends in global wetland area. Marine and Freshwater Research, 65(10), 934941. https://doi.org/10.1071/MF14173

Demnati, F., Allache, F., Ernoul, L., \& Samraoui, B. (2012). Socio-economic stakes and perceptions of wetland management in an arid region: A case study from Chott Merouane, Algeria. AMBIO, 41, 504-512. https://doi.org/10.1007/s13280-012-0285-2

Director of Fisheries, Malda District, 2009 
Dutta, S., \& Sengupta, A. (2015). Wetland Restoration, A Need for Sustenance: A Case Study Chatra Beel of English bazar, District Malda, W.B., India. International Journal of Applied Research, 1(8), 810-814.

Fazal, S., \& Amin, A. (2011). Impact of urban land transformation on water bodies in Srinagar City, India. Journal of Environmental Protection, 2(2), 142153. https://doi.org/10.4236/jep.2011.22016

Ganaie, T.A., Jamal, S., \& Ahmad, W.S. (2020). Changing land use/land cover patterns and growing human population in Wular catchment of Kashmir Valley, India. GeoJournal, 1-18. https://doi.org/10.1007/ s10708-020-10146-y

Halls, A. (1997). Wetlands, biodiversity and the Ramsar convention: the role of the convention on wetlands in the conservation and wise use of biodiversity. In Ramsar Convention Bureau, Gland, Switzerland.

Islam, M. S., Rahman, M. R., Shahabuddin, A.K.M., \& Ahmed, R. (2010). Changes in wetlands in Dhaka city: Trends and physico-environmental consequences. Journal of Life and Earth Science, 5, 3742. https://doi.org/10.3329/jles.v5i0.7348

Jamal, S., \& Ahmad, W.S. (2020). Assessing land use land cover dynamics of wetland ecosystems using Landsat satellite data. SN Applied Sciences, 2(11), 1-24. https:// doi.org/10.1007/s42452-020-03685-z

Jamal, S., \& Ajmal, U. (2020). Assessment of neighbourhood environmental quality using Analytical Hierarchy process with GIS in Azamgarh city. Planning, 73(1), 49-58.

Jamal, S., Ahmad, W.S., Ali, M.A., \& Sharma, A. (2020). Monitoring land use/land cover change detection and urban expansion with Remote Sensing and GIS techniques in Anantnag District of Kashmir Valley. The Geographer, 66(1), 60-69.

Kar, S.K. (2014). Geo hydrological characteristics of wetlands: A study on utilization and environmental impacts in Malda district West Bengal. Department of Geography, Visva Bharti University.

Kar, S.K. (2018). State of Wetland Transformation and Ecological Concerns - A Case Study of Chatra Wetland, English Bazr, West Bengal. International Journal of Research in Geography, 4(2), 1-8. https://doi. org/10.20431/2454-8685.0402001

Khatun, J., \& Anwaruzzaman, A.K.M. (2012). Gorgon Cultivation-A Serious Threat To Wetland Bio-diversity. Golden Research Thoughts, 2(3), 1-9.

Leisangthem, D., Angom, S., Tuboi, C., Badola, R., \& Hussain, S.A. (2012). Socioeconomic considerations in conserving wetlands of northeastern India : A case study of Loktak Lake, Manipur. Cheetal, 50(3\&4), $11-23$.

Mitsch, W.J., \& Gosselink, J.G. (2000). The value of wetlands: importance of scale and landscape setting. Ecological Economics, 35(1), 25-33. https://doi. org/10.1016/S0921-8009(00)00165-8

Mitsch, W.J. \& Gosselink, G.J. (1993). Wetlands (2 $2^{\text {nd }}$ Edition). John Wiley, New York.

ISRO (2010). National Wetland Atlas: West Bengal, SAC/RESA/AFEG/NWIA/ATLAS/09/2010, Space Applications Centre, Ahmedabad, India, 150p.

Pal, S., \& Ziaul, S. K. (2017). Detection of land use and land cover change and land surface temperature in English Bazar urban centre. The Egyptian Journal of Remote Sensing and Space Science, 20(1), 125-145. https://doi.org/10.1016/j.ejrs.2016.11.003

Papa, R.D.S., \& Mamaril Sr, A.C. (2011). History of the biodiversity and limno-ecological studies on Lake Taal with notes on the current state of Philippine limnology. Philippine Science Letters, 4(1), 1-10.

Prasher, K. (2018). The case of India's disappearing wetlands. The Times of India. Retrieved from https://weather. com/en-IN/india/news/news/2018-11-08-the-caseof-indias-disappearing-wetlands

Prasher, K. (2018, November 08). The Case of India's Disappearing Wetlands. The Times of India. Retrieve from https://weather.com/en-IN/india/news/ news/2018-11-08-the-case-of-indias-disappearingwetlands

Ramsar Convention Bureau. (2013). The Ramsar Convention Manual: A Guide to the Convention on Wetlands, Ramsar, Iran, 1971. Ramsar Convention Bureau.

Shafiq, M. U., Islam, Z. U., Abida, A. W., Bhat, M. S., \& Ahmed, P. (2019). Recent trends in precipitation regime of Kashmir valley, India. Disaster Advances, 12(4), 1-11.

Turner, R.K., Van Den Bergh, J.C.J.M., Söderqvist, T., Barendregt, A., Van Der Straaten, J., Maltby, E., \& Van Ierland, E.C. (2000). Ecological-economic analysis of wetlands: scientific integration for management and policy. Ecological economics, 35(1), 7-23. https://doi. org/10.1016/S0921-8009(00)00164-6

Wondefrash, M., Abebe, Y.D., \& Geheb, K. (2003). Wetlands, birds and important bird areas in Ethiopia.

Zhao, S., Fang, J., Miao, S., Gu, B., Tao, S., Peng, C., \& Tang, Z. (2005). The 7-decade degradation of a large freshwater lake in Central Yangtze River, China. Environmental Science \& Technology, 39(2), 431-436. https://doi.org/10.1021/es0490875 


\section{药}

CHITKARA

\section{Creative Space}

Chitkara University, Saraswati Kendra, SCO 160-161, Sector 9-C, Chandigarh, 160009, India

Volume 9, Issue 1

July 2021

ISSN 2321-3892

Copyright: [C 2021 Saleha Jamal and Md Ashif Ali] This is an Open Access article published in Creative Space (Creat. Sp.) by Chitkara University Publications. It is published with a Creative Commons Attribution-CC-BY 4.0 International License. This license permits unrestricted use, distribution, and reproduction in any medium, provided the original author and source are credited. 